\title{
Article \\ Comparative Analysis of Kazakhstani and European Design Specifications: Raft Foundation, Pile Foundation, and Piled Raft Foundation
}

\author{
Assel Zhanabayeva ${ }^{1}$, Nazerke Sagidullina ${ }^{1}$, Jong $\operatorname{Kim}^{1}{ }^{\mathbb{D}}$, Alfrendo Satyanaga ${ }^{1} \mathbb{D}$, Deuckhang Lee ${ }^{2} \mathbb{D}$ \\ and Sung-Woo Moon ${ }^{1, *(D)}$ \\ 1 Department of Civil and Environmental Engineering, School of Engineering and Digital Sciences, \\ Nazarbayev University, 53 Kabanbay Batyr Ave, Nur-Sultan 010000, Kazakhstan; \\ assel.shaldykova@nu.edu.kz (A.Z.); nazerke.sagidullina@nu.edu.kz (N.S.); jong.kim@nu.edu.kz (J.K.); \\ alfrendo.satyanaga@nu.edu.kz (A.S.) \\ 2 Department of Architectural Engineering, Chungbuk National University, Cheongju 28644, Korea; \\ dk@chungbuk.ac.kr \\ * Correspondence: sung.moon@nu.edu.kz; Tel.: +7-7172-70-9096
}

check for updates

Citation: Zhanabayeva, A.; Sagidullina, N.; Kim, J.; Satyanaga, A.; Lee, D.; Moon, S.-W. Comparative Analysis of Kazakhstani and European Design Specifications: Raft Foundation, Pile Foundation, and Piled Raft Foundation. Appl. Sci. 2021, 11, 3099. https://doi.org/ 10.3390/app11073099

Received: 26 January 2021

Accepted: 9 March 2021

Published: 31 March 2021

Publisher's Note: MDPI stays neutral with regard to jurisdictional claims in published maps and institutional affiliations.

Copyright: (c) 2021 by the authors. Licensee MDPI, Basel, Switzerland. This article is an open access article distributed under the terms and conditions of the Creative Commons Attribution (CC BY) license (https:/ / creativecommons.org/licenses/by/ $4.0 /)$.

\begin{abstract}
The introduction of Eurocode in Kazakhstan allows for the application of modern technological innovations and the elimination of technical barriers for the realization of international projects. It is significant to study the international standards and design requirements provided in Eurocode. This study presents a comparative analysis of Kazakhstani and European approaches for the geotechnical design of foundations and provides the design methods in the considered codes of practice. Three different types of foundations (i.e., raft, pile, and piled raft foundations) were designed following SP RK 5.01-102-2013-Foundations of buildings and structures, SP RK 5.01-1032013-Pile foundations, and Eurocode 7: Geotechnical design for the Nur-Sultan soil profile. For all three types of foundations, the calculated results of bearing resistance and elastic settlement showed the conservativeness of Eurocode over SNiP-based Kazakhstani building regulations, as the values of bearing resistance and elastic settlement adhering to Kazakhstani code exceeded the Eurocode values. The difference between the obtained results can be explained by the application of higher values of partial safety factors by Eurocode 7. Sensitivity analysis of the bearing resistance on foundation parameters (i.e., raft foundation width and pile length) for the Kazakhstani and European approaches was performed to support the conclusions of the study.
\end{abstract}

Keywords: raft foundation; pile foundation; piled raft foundation; bearing resistance; elastic settlement; SNiP; SP RK; Eurocode 7

\section{Introduction}

The construction industry in Kazakhstan represents one of the most significant sectors in the country's economy. Progress in the construction field implies better living standards, as well as the safety of the population [1]. The construction industry determines the direction of economic development of a great number of adjacent industries in Kazakhstan [2] Therefore, it is important to understand the significance of building regulations that play a determinative role in the development of a modern country.

A rapid urbanization rate and growth of the construction sector cause the development of construction materials, as well as design technologies. Local designers and engineers used to apply the Kazakhstani technical regulations that consider only traditional design methods and materials [3]. These building regulations were developed based on SNiP code by complementing and providing more details to the design requirements. The traditional $\mathrm{SNiP}$ approach, with proven efficiency and reliability, has been applied in Kazakhstan since Soviet times, for approximately 25-30 years [4]. The main drawback of the national code of practice is the impossibility of the application of new design technologies and 
materials, slowing down the development of the construction industry [3]. However, Kazakhstan still uses the former building regulations as this code of practice considers national circumstances and the privacy of the country.

A considerable part in the solution to this problem is the harmonization of the existing building regulations with Eurocode [1]. Kazakhstan has been in the process of reforming the system of technical regulations in the construction field since 2010. Considering the experience of developed countries, Kazakhstan pursued the idea of integration into the world economic system via the harmonization of codes and design processes. In accordance with the national "100 steps" plan, Eurocode was introduced into the territory of Kazakhstan in 2011 [5]. This reform involves a gradual transition to the national standard SN RK EN, which is identical to Eurocode [6]. Since 2014, Eurocode has been applied in parallel with the existing design code in Kazakhstan [7]. Figure 1 demonstrates the transition of some Commonwealth of Independent States (CIS) countries, including Kazakhstan, to Eurocode.

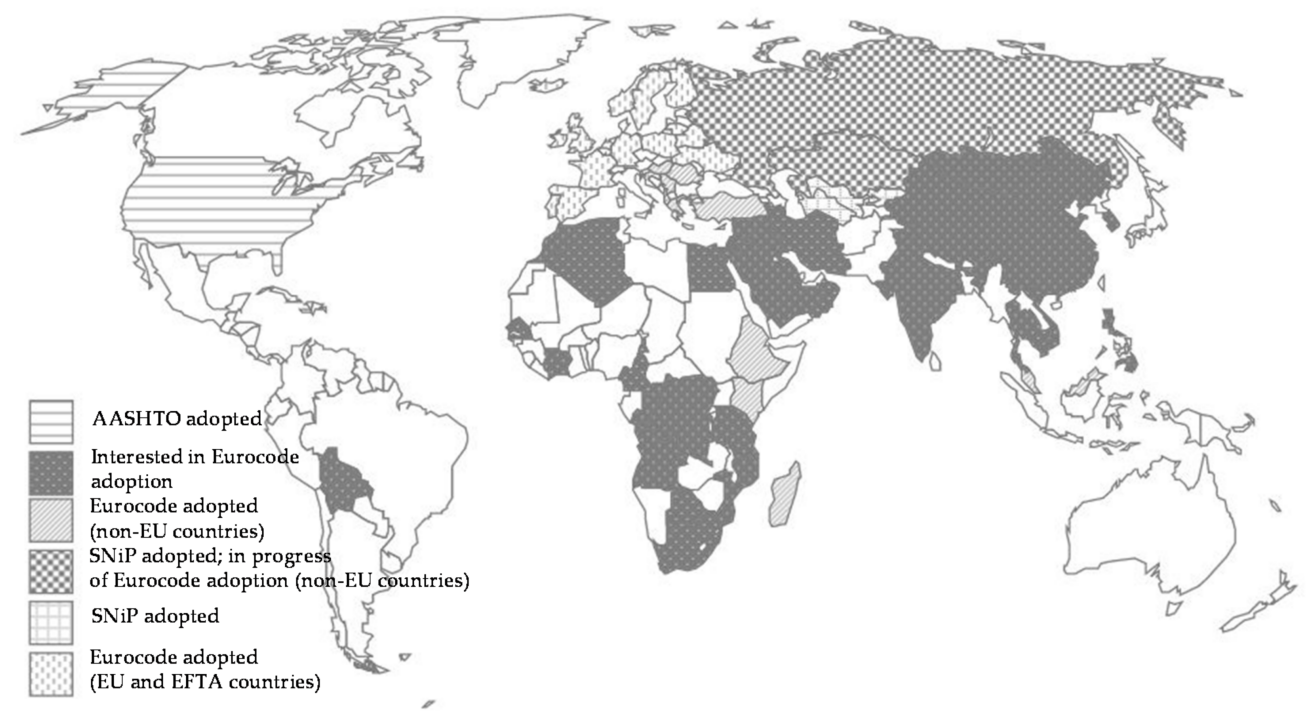

Figure 1. Distribution of design codes around the world (modified from [8]).

Eurocode (EC) represents a flexible and progressive European technical standard used for the design of all types of buildings and structures and different combinations of loads with the application of all types of construction materials. The European Union (EU) decided to create a common European regulatory system for the construction field in 1975 [9]. The aim was to eliminate technical obstacles to international cooperation and to create a unified EU system for design and construction works. All EU member-countries apply EC considering their respective national features, such as climatic, seismic, geological, and economic particularities. EC is being constantly updated in compliance with the newest technological achievements, results of scientific research, and innovations [5].

The government supports the idea of the integration of the Kazakhstani construction industry into the European regulatory system for the realization of large-scale, expensive projects in Kazakhstan [10]. The harmonization of national building regulations with EC (1) contributes to a considerable inflow of foreign investments by solving bureaucratic problems and eliminating administrative barriers, (2) stimulates scientific and technical collaboration between local and European specialists, and (3) allows the application of the same design methods and rules. In addition, the application of EC in Kazakhstan increases the competitiveness of local construction companies, designers, and manufacturers of construction materials on the international level by tightening the discipline, reducing the construction time, and allowing the application of innovative materials and technologies [7].

Almazov [11] described the importance of comparative analysis of national and European standards and familiarization of local specialists with the European approach 
and its application in national practice. The major difference between the considered codes of practice lies in the different mechanisms of economic management and freedom in their application. EC applies the creative approach and provides the requirements for the result of the construction work, whereas the Kazakhstani building regulation provides strict directions in terms of design requirements. That is why the Kazakhstani approach prevents constructors from selecting the most appropriate design solution and introducing new construction technologies [12].

A direct transition from the Kazakhstani building regulations to EC in Kazakhstan is impossible, as the local construction industry is focused on the application of national regulations. The introduction of the European approach must be performed based on a complex programmed approach that gradually considers the particularities of Kazakhstan. The territory of Kazakhstan is distinguished by large variety in nature and climate, which are significantly different from the European ones. The main difficulty in the application of EC in Kazakhstan is the need to consider the specifics of the territory of Kazakhstan and the development of the National Annex (NA) with nationally determined parameters for the application of the European approach.

Raft and pile foundations are two common foundation types for the realization of geotechnical projects in Kazakhstan. Because the rapid urbanization rate in the country requires geotechnical engineers to overcome technical and economic questions associated with the implementation of large-scale construction projects, piled raft foundations are an alternative solution for the support of high-rise buildings, which would be constructed in the near future [13]. The objective of this paper is to (1) perform a comparative analysis of the European and Kazakhstani approaches for the design of raft, pile, and piled raft foundations; (2) identify the differences in the design procedures and the obtained results; and (3) promote familiarization of local specialists with EC. The transition from the Kazakhstani building regulations to Eurocode represents a complex and gradual process demanding a high level of qualification of designers and civil engineers. Thus, the study of the differences between the Kazakhstani and European approaches is crucial for the development of the country's construction industry.

\section{Design Problem and Ground Conditions}

The following design problem in Nur-Sultan, Kazakhstan, is presented to demonstrate the differences between the Kazakhstani and European approaches. The design problem is used for calculating the bearing resistance and elastic settlement of three different types of foundations (plain slab raft, pile, and piled raft foundations), shown in Figure 2.

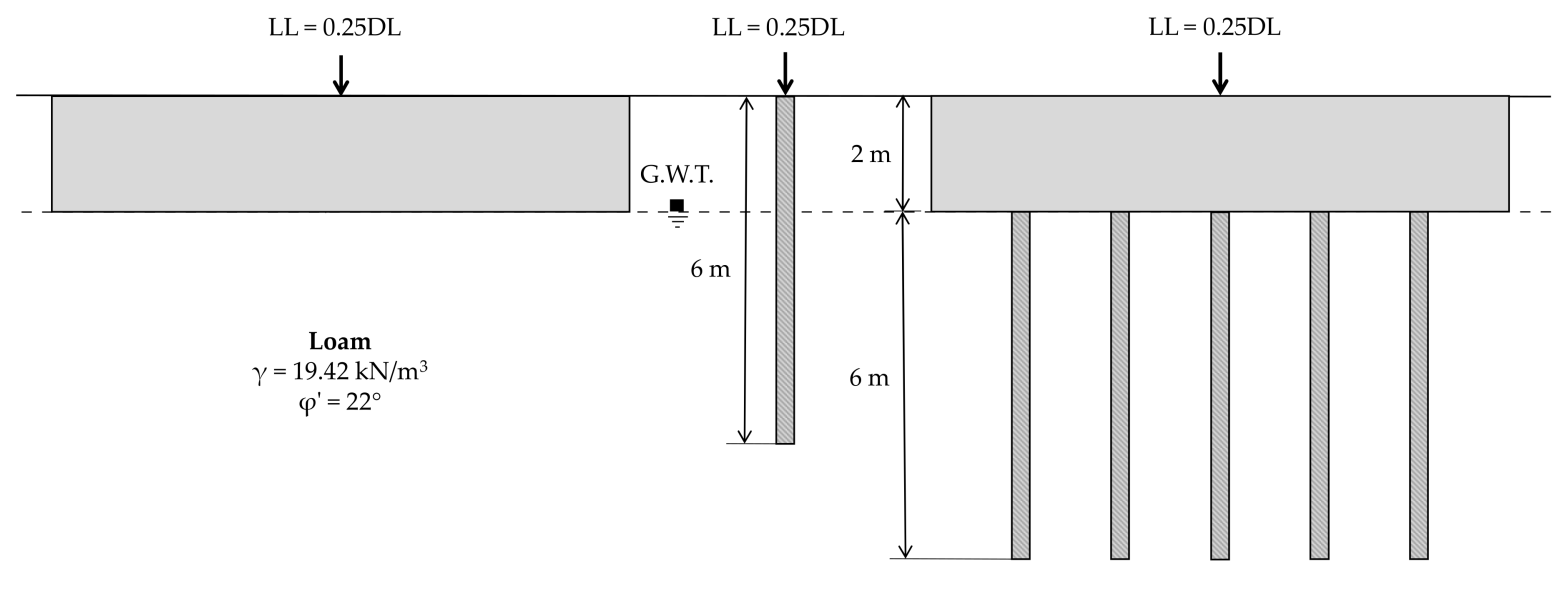

(a) Raft foundation

(b) Pile foundation

(c) Piled raft foundation

Figure 2. Idealized soil profile and designed foundations. 
The soil profile (Figure 2) and engineering properties (Table 1) for loam, which is widely distributed in Nur-Sultan, were used to design the foundations. The groundwater level (G.W.T.) was assumed to be located at a $2 \mathrm{~m}$ depth from the surface level [14]. A comparative analysis of the considered design codes was performed for a raft foundation with length $20 \mathrm{~m}$ and width $10 \mathrm{~m}$, a concrete driven square pile foundation with crosssectional area $300 \mathrm{~mm} \times 300 \mathrm{~mm}$ and length $6 \mathrm{~m}$, and a piled raft foundation representing the combination of the first two foundations. The piles were driven by hydraulic and diesel hammers. The standard structure situation was simulated so that the load ratio of variable to permanent load was 0.25 (Live Load $=0.25 *$ Dead Load). For design simplicity, load eccentricity was neglected.

Table 1. Soil engineering properties in Nur-Sultan city.

\begin{tabular}{ccc}
\hline Soil Type & Loam & Note \\
\hline Water content $(\mathrm{w}), \%$ & 19.10 \\
\hline Effective friction angle, $\left(\varphi^{\prime}\right),{ }^{\circ}$ & 22.00 & Obtained from Alibekova and Zhussupbekov [14] \\
\hline Modulus of deformation $(\mathrm{E}), \mathrm{MPa}$ & 30.00 & 18.00 \\
\hline Liquid limit $(\mathrm{LL}), \%$ & 12.00 & 0.09 \\
\hline Plastic limit $(\mathrm{PL}), \%$ & 19.42 & 20.10 \\
\hline Plasticity index $(\mathrm{PI}), \%$ & 15.00 & Determined as the average value of Cangir and Dipova [15], \\
\hline Snit weight $(\gamma), \mathrm{kN} / \mathrm{m}^{3}$ & 118.00 & Schofield and Wroth [16], Wroth and Wood [17]
\end{tabular}

\section{Review of the Design Codes}

\subsection{Pile Foundation Design}

The design procedure for a single pile adhering to the Kazakhstani approach is provided in SP RK 5.01-103-2013-Pile foundations [18]. The bearing resistance of a single driven pile is calculated as a summation of soil resistances under the pile base and on the shaft surface, referring to Equation (1). The parameters for Equation (1) are explained in Table 2.

$$
\mathrm{F}_{\mathrm{d}}=\gamma_{\mathrm{c}}\left(\gamma_{\mathrm{cR}} \mathrm{RA}+\mathrm{u} \sum \gamma_{\mathrm{cf}} \mathrm{f}_{\mathrm{i}} \mathrm{h}_{\mathrm{i}}\right)
$$

Table 2. Description of parameters in SP RK 5.01-103-2013-Pile foundations.

\begin{tabular}{|c|c|c|c|}
\hline Notation & Description & Value & Notes \\
\hline$\gamma_{\mathrm{c}}$ & Partial factor on operational conditions & 0.7 & Taken from Table 8 of SP RK 5.01-103-2013 \\
\hline $\mathrm{R}$ & Design resistance of soil under the pile base $(\mathrm{kPa})$ & 6000 & $\begin{array}{l}\text { Taken from Table } 1 \text { of SP RK 5.01-103-2013 } \\
\text { (Figure S1 in the Supplementary Data) }\end{array}$ \\
\hline A & Cross-sectional area of pile base, $\mathrm{m}^{2}$ & 0.05 & - \\
\hline $\mathrm{u}$ & Outer perimeter of pile shaft, $\mathrm{m}$ & 1.2 & - \\
\hline $\mathrm{f}_{\mathrm{i}}$ & Design resistance of $i$ th soil layer on the pile shaft $(\mathrm{kPa})$ & To be calculated & $\begin{array}{l}\text { Taken from Table } 2 \text { of SP RK 5.01-103-2013 } \\
\text { (Figure S2 in the Supplementary Data) }\end{array}$ \\
\hline$h_{i}$ & Thickness of $i$ th soil layer in contact with pile shaft, $\mathrm{m}$ & To be calculated & - \\
\hline$\gamma_{\mathrm{cR}}$ & $\begin{array}{l}\text { Partial factor on operational conditions of soil under } \\
\text { the pile base }\end{array}$ & 1 & \multirow{2}{*}{ Taken from Table 3 (SP RK 5.01-103-2013) } \\
\hline$\gamma_{\mathrm{cf}}$ & $\begin{array}{c}\text { Partial factor on operational conditions of soil on the surface } \\
\text { of pile shaft }\end{array}$ & 1 & \\
\hline
\end{tabular}


Table 3. Partial factors for geotechnical Ultimate Limit States.

\begin{tabular}{|c|c|c|c|c|c|c|c|c|}
\hline \multirow{2}{*}{ Design Approach } & \multicolumn{2}{|c|}{$\gamma_{\mathrm{G}}$} & \multicolumn{2}{|c|}{$\gamma_{\mathrm{Q}}$} & \multirow{2}{*}{$\gamma_{\mathrm{c}^{\prime}}$} & \multirow{2}{*}{$\gamma_{\varphi^{\prime}}$} & \multirow{2}{*}{$\gamma_{\mathrm{b}}$} & \multirow{2}{*}{$\gamma_{\mathrm{s}}$} \\
\hline & Unfav. & Fav. & Unfav. & Fav. & & & & \\
\hline DA1-1 & 1.35 & 1.0 & 1.5 & 0 & 1.0 & 1.0 & 1.0 & 1.0 \\
\hline DA1-2 & 1.0 & 1.0 & 1.3 & 0 & 1.25 & 1.25 & 1.0 & 1.0 \\
\hline DA2 & 1.35 & 1.0 & 1.5 & 0 & 1.0 & 1.0 & 1.1 & 1.1 \\
\hline DA3 & 1.0 & 1.0 & 1.3 & 0 & 1.25 & 1.25 & 1.0 & 1.0 \\
\hline
\end{tabular}

According to SP RK 5.01-103-2013-Pile foundations, a single-pile design should satisfy the following condition:

$$
\mathrm{N} \leq \frac{\mathrm{F}_{\mathrm{d}}}{\gamma_{\mathrm{k}}}
$$

where $\mathrm{N}$ is the design load applied on the pile $(\mathrm{kN}) ; \mathrm{F}_{\mathrm{d}}$ is the design bearing resistance of the pile $(\mathrm{kN})$; and $\gamma_{\mathrm{k}}$ is the reliability coefficient.

The elastic settlement of a single pile is determined in accordance with Annex G of SP RK 5.01-103-2013-Pile foundations using the following equation:

$$
s=\beta \frac{N}{G_{1} 1}
$$

where $N$ is the vertical load applied on the pile $(M N) ; G_{1}$ is the shear modulus of soil (MPa); 1 is the pile length $(\mathrm{m})$; and $\beta$ is a dimensionless coefficient.

The procedure for the design of a pile foundation is outlined in Section 7 of Eurocode 7 [19]. The design resistance of a pile foundation is determined using the following equation:

$$
\mathrm{R}_{\mathrm{c} ; \mathrm{d}}=\frac{\mathrm{R}_{\mathrm{b} ; \mathrm{k}}}{\gamma_{\mathrm{b}}}+\frac{\mathrm{R}_{\mathrm{s} ; \mathrm{k}}}{\gamma_{\mathrm{s}}}
$$

where $R_{b ; k}$ and $R_{s ; k}$ are the characteristic values of base and shaft resistance, respectively $(\mathrm{kN}) ; \gamma_{\mathrm{b}}$ and $\gamma_{\mathrm{s}}$ are partial factors of base and shaft resistance, respectively, for driven piles, provided in Table 3.

The characteristic values of base and shaft resistance can be obtained using the following equations:

$$
\begin{gathered}
\mathrm{R}_{\mathrm{b} ; \mathrm{k}}=\mathrm{A}_{\mathrm{b}} \mathrm{q}_{\mathrm{b} ; \mathrm{k}} \\
\mathrm{R}_{\mathrm{s} ; \mathrm{k}}=\sum \mathrm{A}_{\mathrm{s} ; \mathrm{i}} \mathrm{q}_{\mathrm{s} ; \mathrm{i} ; \mathrm{k}}
\end{gathered}
$$

where $\mathrm{q}_{\mathrm{b} ; \mathrm{k}}$ and $\mathrm{q}_{\mathrm{s} ; \mathrm{i} ; \mathrm{k}}$ are the characteristic values of unit base and shaft resistance, respectively $\left(\mathrm{kN} / \mathrm{m}^{2}\right) ; \mathrm{A}_{\mathrm{b}}$ is the pile base area $\left(\mathrm{m}^{2}\right)$; and $\mathrm{A}_{\mathrm{s} ; \mathrm{i}}$ is the pile shaft area in the $i$ th soil layer $\left(\mathrm{m}^{2}\right)$.

The limit state analysis adhering to Eurocode 7 requires the following condition to be satisfied:

$$
\mathrm{V}_{\mathrm{d}} \leq \mathrm{R}_{\mathrm{d}}
$$

where $V_{d}$ is the vertical load acting on the foundation $(k N)$ and $R_{d}$ is the design bearing resistance $(\mathrm{kN})$.

Eurocode 7 provides different design approaches (DA1-1, DA1-2, DA2, and DA3) for the design of buildings and structures indicated in the National Annexes. The distribution of design approaches in EU countries for the design of pile foundations is summarized in Figure 3. The selection of design approaches by the countries is explained by their construction traditions and experience [20]. The combinations of partial factors on actions $(A)$, material properties $(M)$, and resistances $(R)$ for all design approaches are given in Table 4. DA1 and DA3 are based on the Material Strength Design (MSD) method and apply partial factors on actions and material strength parameters either simultaneously or 
separately. However, DA2 applies partial factors on actions and resistance simultaneously. This approach represents a method similar to Load and Resistance Factor Design (LRFD), widely applied by American codes of practice [21].

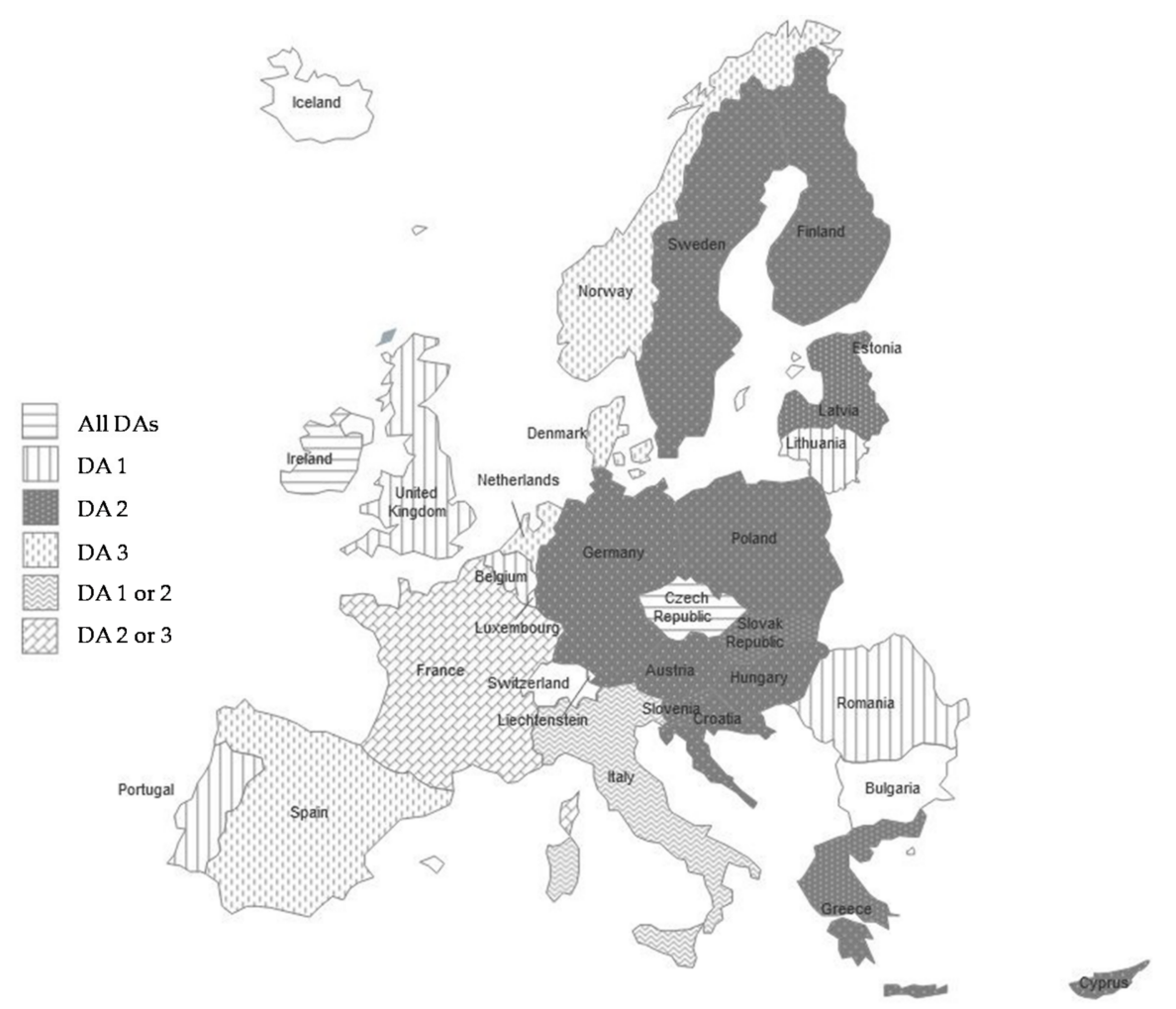

Figure 3. Design approaches in EU countries for pile foundations (modified from [8]).

Table 4. Design approaches and combinations.

\begin{tabular}{|c|c|}
\hline Design Approach & Combination \\
\hline DA1-1 & $\mathrm{A} 1$ “+” M1 “+” R1 \\
\hline DA1-2 & $\mathrm{A} 2$ “+” M2 “+” R1 \\
\hline DA2 & $\mathrm{A} 1$ “+” M1 “+” R2 \\
\hline DA3 & $\mathrm{A} 2$ “+” M2 “+” R3 \\
\hline
\end{tabular}

The value of the design vertical load acting on the foundation is determined in accordance with Equation (8):

$$
\mathrm{V}_{\mathrm{d}}=\gamma_{\mathrm{G}} *\left(\mathrm{~W}_{\mathrm{Gk}}+\mathrm{G}_{\mathrm{k}}\right)+\gamma_{\mathrm{Q}} * \mathrm{Q}_{\mathrm{k}}
$$

where $G_{k}$ and $Q_{k}$ are the characteristic permanent and variable loads, respectively $(k N)$; $\mathrm{W}_{\mathrm{Gk}}$ is the foundation self-weight $(\mathrm{kN}) ; \gamma_{\mathrm{G}}$ and $\gamma_{\mathrm{Q}}$ are the partial factors on permanent and variable loads, respectively, provided in Table 3 .

When adhering to the European approach, the elastic settlement of a single pile can be determined based on elastic theory using Equation (9) [22]:

$$
\mathrm{s}=\frac{\mathrm{P}}{\mathrm{dE}_{\mathrm{s}}} \mathrm{I}_{\mathrm{p}}
$$

where $\mathrm{P}$ is the load acting on the foundation $(\mathrm{kN})$; $\mathrm{d}$ is the pile diameter $(\mathrm{m})$; $\mathrm{E}_{\mathrm{s}}$ is the Young's modulus of the soil (MPa); and $\mathrm{I}_{\mathrm{p}}$ is the pile displacement influence factor. 


\subsection{Raft Foundation Design}

The Kazakhstani approach for the determination of the bearing resistance and elastic settlement of a raft foundation is outlined in SP RK 5.01-102-2013-Foundations of buildings and structures [23]. The bearing resistance of a raft foundation adhering to the Kazakhstani approach can be calculated using the equation below, the parameters for which are explained in Table 5.

$$
\mathrm{R}=\frac{\gamma_{\mathrm{c} 1} \gamma_{\mathrm{c} 2}}{\mathrm{k}}\left[\mathrm{M}_{\gamma} \mathrm{k}_{\mathrm{z}} \mathrm{b} \gamma_{\mathrm{II}}+\mathrm{M}_{\mathrm{q}} \mathrm{d}_{\mathrm{I}} \gamma_{\mathrm{II}}^{\prime}+\left(\mathrm{M}_{\mathrm{q}}-1\right) \mathrm{d}_{\mathrm{b}} \gamma_{\mathrm{II}}^{\prime}+\mathrm{M}_{\mathrm{c}} \mathrm{c}_{\mathrm{II}}\right]
$$

Table 5. Description of parameters in SP RK 5.01-102-2013-Foundations of buildings and structures.

\begin{tabular}{|c|c|c|c|}
\hline Notation & Description & Value & Notes \\
\hline$\gamma_{\mathrm{c} 1}$ & \multirow{2}{*}{ Partial factors on operational conditions } & 1.25 & \multirow{2}{*}{$\begin{array}{l}\text { Taken according to Table } 4 \text { of SP RK } \\
5.01-102-2013\end{array}$} \\
\hline$\gamma_{\mathrm{c} 2}$ & & 1 & \\
\hline $\mathrm{k}$ & Dimensionless coefficient & 1 & $\begin{array}{l}\text { Depends on the method of determination of } \\
\text { strength characteristics of soil ( } \varphi \text { and } c)\end{array}$ \\
\hline $\mathrm{M}_{\gamma}$ & $\begin{array}{l}\text { Dimensionless coefficients representing a } \\
\text { function of frictional angle, load inclination, and } \\
\text { shape of the foundation }\end{array}$ & 0.61 & \multirow{3}{*}{$\begin{array}{c}\text { Taken according to Table } 5 \text { of SP RK } \\
\text { 5.01-102-2013 (Figure S3 in the } \\
\text { Supplementary Data) }\end{array}$} \\
\hline $\mathrm{M}_{\mathrm{q}}$ & & 3.44 & \\
\hline $\mathrm{M}_{\mathrm{c}}$ & & 6.04 & \\
\hline $\mathrm{k}_{\mathrm{z}}$ & Dimensionless coefficient & 1 & $\begin{array}{c}\text { At } \mathrm{b}<10 \mathrm{~m}, \mathrm{k}_{\mathrm{z}} \text { is taken to be } 1 ; \text { at } \mathrm{b} \geq 10 \mathrm{~m}, \\
\mathrm{k}_{\mathrm{z}}=\frac{\mathrm{z}_{0}}{\mathrm{~b}}+0.2\left(\text { here, } \mathrm{z}_{0}=8 \mathrm{~m}\right)\end{array}$ \\
\hline $\mathrm{b}$ & Width of the foundation base (m) & 10 & - \\
\hline$\gamma_{\mathrm{II}}$ & $\begin{array}{l}\text { Average design values of the specific weight of } \\
\text { soil under the foundation base }\left(\mathrm{kN} / \mathrm{m}^{3}\right)\end{array}$ & 19.42 & - \\
\hline$\gamma_{\mathrm{II}}^{\prime}$ & $\begin{array}{l}\text { Average design values of the specific weight of } \\
\text { soil above the foundation base }\left(\mathrm{kN} / \mathrm{m}^{3}\right)\end{array}$ & 19.42 & - \\
\hline $\mathrm{c}_{\mathrm{II}}$ & $\begin{array}{l}\text { Design value of the specific cohesion of soil } \\
\text { below the foundation base }(\mathrm{kPa})\end{array}$ & 15 & - \\
\hline $\mathrm{d}_{\mathrm{I}}$ & Depth of the foundation $(\mathrm{m})$ & 1.5 & - \\
\hline$d_{b}$ & Depth of the basement (m) & 0 & - \\
\hline
\end{tabular}

The elastic settlement of a raft foundation adhering to the Kazakhstani approach is determined in accordance with Equation (11):

$$
\mathrm{s}=\frac{\mathrm{pbk}_{\mathrm{c}}}{\mathrm{k}_{\mathrm{m}}} \sum \frac{\mathrm{k}_{\mathrm{i}}-\mathrm{k}_{\mathrm{i}-1}}{\mathrm{E}_{\mathrm{i}}}
$$

where $\mathrm{p}$ is the average pressure under the foundation base $(\mathrm{kPa}) ; \mathrm{b}$ is the width of the foundation $(\mathrm{m}) ; \mathrm{k}_{\mathrm{c}}, \mathrm{k}_{\mathrm{m}}$, and $\mathrm{k}_{\mathrm{i}}$ are dimensionless coefficients; and $\mathrm{E}_{\mathrm{i}}$ is the modulus of deformation of the soil $(\mathrm{kPa})$.

The European approach for the calculation of the design resistance of a raft foundation for a long-term design situation is outlined in Annex D of Eurocode 7 [19]. The bearing resistance of a raft foundation adhering to the European approach can be calculated using Equation (12), the parameters for which are explained in Table 6.

$$
\mathrm{R} / \mathrm{A}^{\prime}=\mathrm{c}^{\prime} \mathrm{N}_{\mathrm{c}} \mathrm{b}_{\mathrm{c}} \mathrm{s}_{\mathrm{c}} \mathrm{i}_{\mathrm{c}}+\mathrm{q}^{\prime} \mathrm{N}_{\mathrm{q}} \mathrm{b}_{\mathrm{q}} \mathrm{s}_{\mathrm{q}} \mathrm{i}_{\mathrm{q}}+\frac{1}{2} \gamma^{\prime} \mathrm{B}^{\prime} \mathrm{N}_{\gamma} \mathrm{b}_{\gamma} \mathrm{s}_{\gamma} \mathrm{i}_{\gamma}
$$


Table 6. Description of parameters in Eurocode 7.

\begin{tabular}{|c|c|c|c|}
\hline Notation & Description & Value & Notes \\
\hline $\mathrm{B}^{\prime}$ & Effective width of the foundation (m) & 10 & - \\
\hline $\mathrm{L}^{\prime}$ & Effective length of the foundation (m) & 20 & - \\
\hline $\mathrm{A}^{\prime}$ & $\begin{array}{l}\text { Design effective area of the } \\
\text { foundation }\left(\mathrm{m}^{2}\right)\end{array}$ & 200 & $\mathrm{~A}^{\prime}=\mathrm{B}^{\prime} * \mathrm{~L}^{\prime}$ \\
\hline$c^{\prime}$ & Design effective cohesion $(\mathrm{kPa})$ & To be calculated & - \\
\hline $\mathrm{q}^{\prime}$ & $\begin{array}{c}\text { Design effective overburden pressure at } \\
\text { the level of the foundation } \\
\text { base }\left(\mathrm{kN} / \mathrm{m}^{2}\right)\end{array}$ & 19.42 & $\mathrm{q}^{\prime}=\gamma^{\prime} * \mathrm{~d}$ \\
\hline$\gamma^{\prime}$ & $\begin{array}{l}\text { Design effective weight density of soil } \\
\text { below the foundation level }\left(\mathrm{kN} / \mathrm{m}^{3}\right)\end{array}$ & To be calculated & - \\
\hline $\mathrm{N}_{\mathrm{q}}$ & \multirow{3}{*}{ Bearing resistance factors } & \multirow{3}{*}{ To be calculated } & $\mathrm{N}_{\mathrm{q}}=\mathrm{e}^{\pi \tan \varphi^{\prime}} \tan ^{2}\left(\frac{\pi}{4}+\frac{\varphi^{\prime}}{2}\right)$ \\
\hline $\mathrm{N}_{\mathrm{c}}$ & & & $\mathrm{N}_{\mathrm{c}}=\left(\mathrm{N}_{\mathrm{q}}-1\right) \cot \varphi^{\prime}$ \\
\hline $\mathrm{N}_{\gamma}$ & & & $\mathrm{N}_{\gamma}=2\left(\mathrm{~N}_{\mathrm{q}}-1\right) \tan \varphi^{\prime}$ \\
\hline $\mathrm{b}_{\mathrm{q}}$ & \multirow{3}{*}{ Inclination factors } & \multirow{3}{*}{ To be calculated } & $\mathrm{b}_{\mathrm{q}}=\left(1-\alpha \tan \varphi^{\prime}\right)^{2}$ \\
\hline $\mathrm{b}_{\mathrm{c}}$ & & & $\mathrm{b}_{\mathrm{c}}=\mathrm{b}_{\mathrm{q}}-\left(1-\mathrm{b}_{\mathrm{q}}\right) /\left(\mathrm{N}_{\mathrm{c}} \tan \varphi^{\prime}\right)$ \\
\hline $\mathrm{b}_{\gamma}$ & & & $\mathrm{b}_{\gamma}=\left(1-\alpha \tan \varphi^{\prime}\right)^{2}$ \\
\hline $\mathrm{s}_{\mathrm{q}}$ & \multirow{3}{*}{ Shape factors } & \multirow{3}{*}{ To be calculated } & $\mathrm{s}_{\mathrm{q}}=1+\sin \varphi^{\prime}$ for a square shape \\
\hline $\mathrm{s}_{\mathrm{c}}$ & & & 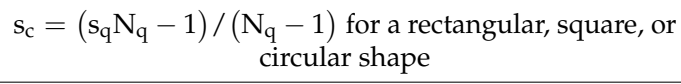 \\
\hline $\mathrm{s}_{\gamma}$ & & & Equal to 0.7 for a square shape \\
\hline$i_{c}$ & \multirow[b]{3}{*}{$\begin{array}{l}\text { Inclination factors of the load caused by } \\
\text { horizontal load } \mathrm{H}\end{array}$} & \multirow[b]{3}{*}{ To be calculated } & $\mathrm{i}_{\mathrm{c}}=\mathrm{i}_{\mathrm{q}}-1\left(1-\mathrm{i}_{\mathrm{q}}\right) /\left(\mathrm{N}_{\mathrm{c}} \tan \varphi^{\prime}\right)$ \\
\hline $\mathrm{i}_{\mathrm{q}}$ & & & $\mathrm{i}_{\mathrm{q}}=\left[1-\frac{\mathrm{H}}{\mathrm{V}+\mathrm{A}^{\prime} \mathrm{c}^{\prime} \cot \varphi^{\prime}}\right]^{\mathrm{m}}$ \\
\hline $\mathrm{i}_{\gamma}$ & & & $\begin{array}{c}\mathrm{i}_{\gamma}=\left[1-\frac{\mathrm{H}}{\mathrm{V}+\mathrm{A}^{\prime} \mathrm{c}^{\prime} \cot \varphi^{\prime}}\right]^{\mathrm{m}+1} \\
\text { where: } \\
\mathrm{m}=\mathrm{m}_{\mathrm{B}}=\left[2+\left(\mathrm{B}^{\prime} / \mathrm{L}^{\prime}\right)\right] /\left[1+\left(\mathrm{B}^{\prime} / \mathrm{L}^{\prime}\right)\right] \text { where } \mathrm{H} \text { acts in the } \\
\text { direction of } \mathrm{B} ; \\
\mathrm{m}=\mathrm{m}_{\mathrm{L}}=\left[2+\left(\mathrm{L}^{\prime} / \mathrm{B}^{\prime}\right)\right] /\left[1+\left(\mathrm{L}^{\prime} / \mathrm{B}^{\prime}\right)\right] \text { where } \mathrm{H} \text { acts in the } \\
\text { direction of } \mathrm{L} ;\end{array}$ \\
\hline$\alpha$ & $\begin{array}{l}\text { Inclination of the foundation base to } \\
\text { the horizontal }\end{array}$ & 0 & e \\
\hline
\end{tabular}

Eurocode 7 applies the adjusted elasticity method for the determination of the elastic settlement of a raft foundation in accordance with Equation (13):

$$
\mathrm{s}=\mathrm{pBf} / \mathrm{E}_{\mathrm{m}}
$$

where $\mathrm{p}$ is the net bearing pressure linearly distributed on the foundation base $(\mathrm{kPa}) ; \mathrm{f}$ is the settlement coefficient; and $\mathrm{E}_{\mathrm{m}}$ is the design modulus of deformation of the soil $(\mathrm{kPa})$.

When adhering to EC 7, the values of partial factors on permanent and variable loads from Table 3 for different design approaches are considered for the calculation of the vertical load action on the raft foundation.

\subsection{Piled Raft Foundation Design}

A piled raft foundation is a composite construction that has recently been widely applied around the world, especially for the construction of multistory buildings/high-rise buildings, in order to (1) increase the load capacity, (2) decrease the foundation settlement, and (3) reduce the construction cost. 
The bearing resistance of a piled raft foundation is calculated using the formula below, where the total geotechnical resistance is equal to the summation of the resistance of the raft, $R_{\text {raft }}$ and the resistance of the piles, $R_{\text {pile, i }}$ [24].

$$
\mathrm{R}_{\text {tot }}=\sum \mathrm{R}_{\text {pile, } \mathrm{i}}+\mathrm{R}_{\mathrm{raft}}
$$

The Kazakhstani approach determines the elastic settlement of a piled raft foundation using Equation (15):

$$
\mathrm{s}_{\mathrm{f}}=\gamma_{\mathrm{f}} * \frac{\sum \mathrm{P}}{\mathrm{K}_{\mathrm{f}}}
$$

where $\gamma_{\mathrm{f}}$ is the safety factor, equal to 1.2; $\mathrm{P}$ is the load applied on the foundation $(\mathrm{kN})$; and $\mathrm{K}_{\mathrm{f}}$ is the total piled raft foundation stiffness $(\mathrm{kN} / \mathrm{m})$, equal to the summation of the stiffness of all piles and the stiffness of the raft.

When adhering to the European approach, the elastic settlement of a piled raft foundation is determined by the following equation [25]:

$$
\mathrm{s}=\frac{\mathrm{P}}{\mathrm{K}_{\mathrm{PR}}}
$$

where $\mathrm{P}$ is the load applied on the piled raft foundation $(\mathrm{kN})$ and $\mathrm{K}_{\mathrm{PR}}$ is the stiffness of the piled raft foundation $(\mathrm{kN} / \mathrm{m})$.

The stiffness of a piled raft foundation is determined in accordance with Equation (17):

$$
K_{P R}=\frac{K_{P G}+\left(1-2 \alpha_{\mathrm{rp}}\right) K_{R}}{1-\alpha_{\mathrm{rp}}^{2}\left(\frac{K_{\mathrm{R}}}{K_{\mathrm{PG}}}\right)}
$$

where $\mathrm{K}_{\mathrm{PR}}, \mathrm{K}_{\mathrm{PG}}$, and $\mathrm{K}_{\mathrm{R}}$ are the stiffness of the piled raft, pile group, and raft, respectively $(\mathrm{kN} / \mathrm{m}) ; \alpha_{\mathrm{rp}}$ is the interaction factor of the raft with the pile.

\section{Results and Discussion}

The performed comparative analysis of the Kazakhstani and European approaches shows the similarities and differences between the applied methods for the geotechnical design of raft, pile, and piled raft foundations. It was performed by determining the over-design factor (ODF), representing the degree of safety of the designed foundations. The following condition must be satisfied:

$$
\mathrm{ODF}=\frac{\mathrm{R}_{\mathrm{d}}}{\mathrm{E}_{\mathrm{d}}} \geq 1
$$

where $R_{d}$ is the design resistance $(k N)$ and $E_{d}$ is the design effect of actions $(k N)$.

The values of vertical load acting on the raft and pile foundations were calculated based on the assumption that the ODF for the Kazakhstani approach was equal to unity (Table 7). Considering the standard structure design and the assumed relationship between the permanent and variable loads (Live Load $=0.25 *$ Dead Load), the vertical load acting on raft and pile foundations adhering to the European approach was identified.

Table 7. Loads applied on the designed foundations.

\begin{tabular}{ccc}
\hline Applied Load & Raft Foundation & Pile Foundation \\
\hline Permanent load $(\mathrm{kN})$ & 60,500 & 240 \\
\hline Variable load $(\mathrm{kN})$ & 15,100 & 60 \\
\hline
\end{tabular}

Figure 4 shows the ODF values for the Kazakhstani and European approaches to raft and pile foundations. For the Kazakhstani approach, the ODF was assumed to be equal to unity, whereas the ODF for the European approach was greater by $6 \%$ to $38 \%$ for both raft 
and pile foundations. The difference in the ODF results is attributed to the application of partial safety factors on permanent and variable loads for the determination of the design resistance in the different design approaches (i.e., DA1-1, DA1-2, DA2, and DA3) of EC 7.

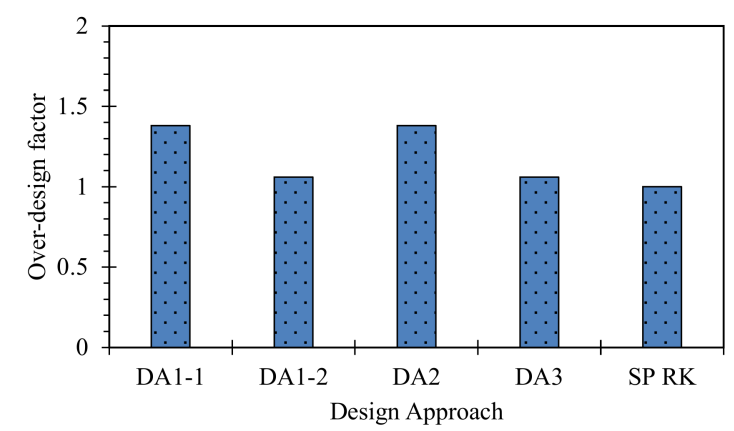

(a)

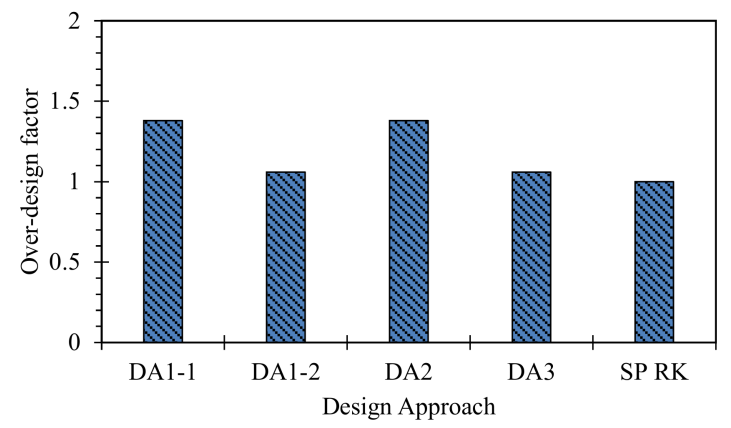

(b)

Figure 4. Over-design factors of the (a) raft foundation and (b) pile foundation.

The obtained values of vertical load applied on the designed foundations allowed for the calculation of both the bearing resistance and elastic settlement of raft and pile foundations for SP RK and EC 7. First, the design bearing resistance of the raft foundation was defined by Equations (10) and (12), adhering to the Kazakhstani and European approaches, respectively. As the design problem involves the consideration of cohesive soil, the Kazakhstani approach determines the bearing resistance based on mainly the liquidity index (Figures S1 and S2), whereas the European approach calculates it by considering primarily the undrained shear strength of the soil. A comparison of the design approaches shows that both of the equations apply dimensionless coefficients considering the effective cohesion, overburden pressure, and unit weight of soil for the design of a raft foundation (i.e., $\mathrm{M}_{\gamma}$, $\mathrm{M}_{\mathrm{q}}$, and $\mathrm{M}_{\mathrm{c}}$ for SP RK and $\mathrm{N}_{\gamma} \mathrm{b}_{\gamma} \mathrm{s}_{\gamma} \mathrm{i}_{\gamma}, \mathrm{N}_{\mathrm{q}} \mathrm{b}_{\mathrm{q}} \mathrm{s}_{\mathrm{q}} \mathrm{i}_{\mathrm{q}}$, and $\mathrm{N}_{\mathrm{c}} \mathrm{b}_{\mathrm{c}} \mathrm{s}_{\mathrm{c}} \mathrm{i}_{\mathrm{c}}$ for EC 7). The Kazakhstani and European approaches calculate the bearing resistance of a pile foundation by summing the design resistances of the soil under the pile base and on the pile shaft, as indicated in Equations (1) and (4). However, SP RK applies the partial factors on operational conditions under the pile base and on the surface of the pile shaft (i.e., $\gamma_{\mathrm{cR}}$ and $\gamma_{\mathrm{cf}}$ ) and EC 7 uses the partial factors on the base and shaft resistances (i.e., $\gamma_{b}$ and $\gamma_{s}$ ) when calculating the pile foundation bearing resistance. The Kazakhstani approach applies a reduction factor when calculating the bearing resistance of a pile foundation, as provided in Equation (2). By contrast, the European approach directly calculates the factored geotechnical resistance of the pile foundation by using the factored strength parameters.

Second, the elastic settlement of the raft foundation was determined by Equations (11) and (13). Raft foundation settlement is calculated by the application of the adjusted elasticity theory in EC 7, whereas SP RK applies the linearly deformable layer method. However, both of the methods consider a settlement coefficient, which depends on the foundation dimensions. Comparing the methods for the determination of the elastic settlement of a pile foundation, the Kazakhstani approach involves the shear modulus, as in Equation (3), whereas the European approach applies the elasticity modulus, as in Equation (9).

Comparisons of the calculated results of the bearing resistance and elastic settlement of raft and pile foundations adhering to the Kazakhstani approach and European approach are provided in Figures 5 and 6, respectively. The obtained results show that the EC 7 results exceeded the values from the Kazakhstani approach for both raft and pile foundations. The European approach resulted in 1.2 to 2.2 times and 1.15 to 1.5 times higher values of bearing resistance for raft and pile foundations, respectively. Moreover, the performed comparative analysis revealed that EC 7 values exceeded SP RK values of elastic settlement by 2.0 to 3.8 times and 1.7 to 2.3 times for raft and pile foundations, respectively. 


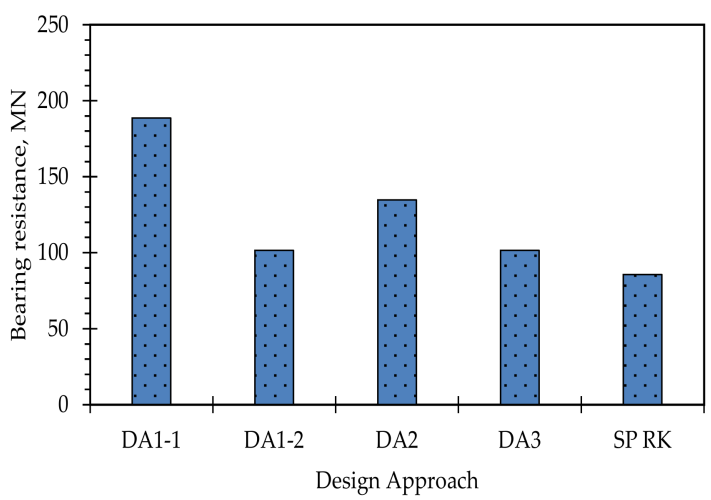

(a)

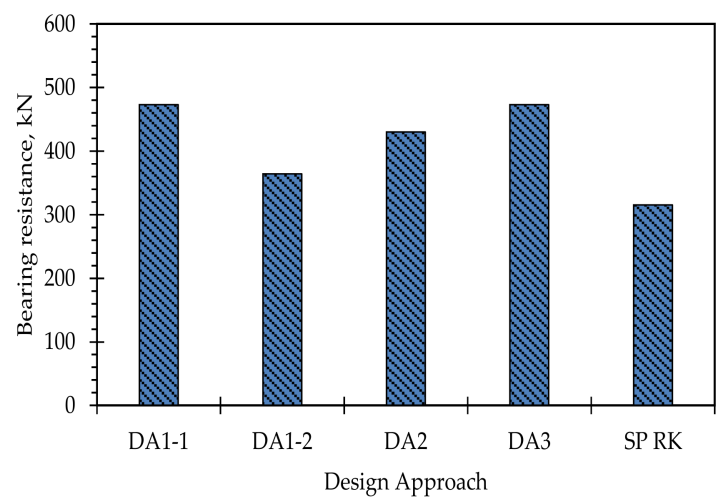

(b)

Figure 5. Bearing resistance values of the (a) raft foundation and (b) pile foundation.

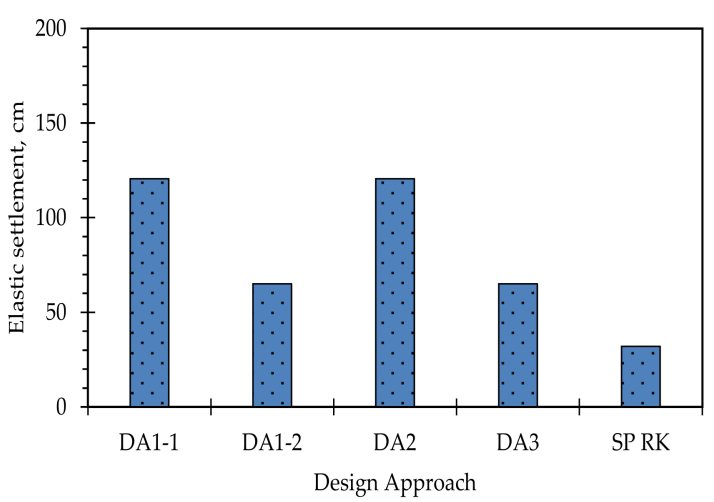

(a)

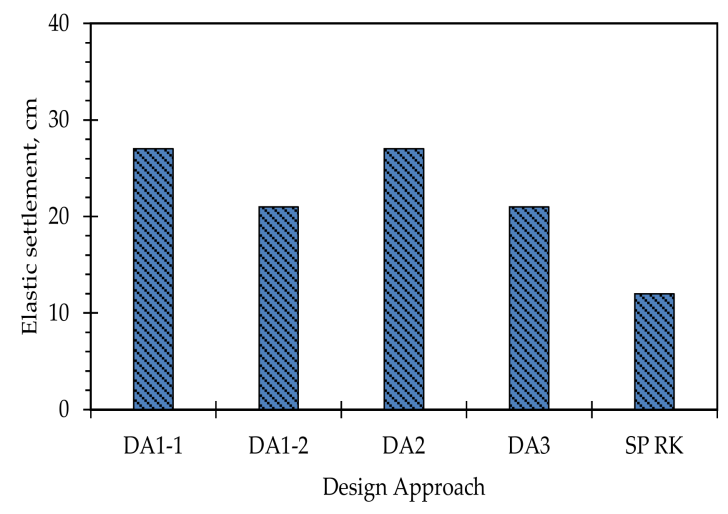

(b)

Figure 6. Elastic settlement values of the (a) raft foundation and (b) pile foundation.

The higher values of vertical load applied on the raft and pile foundations in the European approach contributed to the higher results for both bearing resistance and elastic settlement. The applied values of partial safety factors differ for the European and Kazakhstani codes, mainly because of the differences in climatic and geological features. EC 7 applies higher values of partial factors of safety in the design of buildings and structures that allow higher results to be obtained than by adhering to the Kazakhstani regulation.

The values of bearing resistance of the piled raft foundation were obtained as the combination of the resistances of the raft and pile foundations and resulted in 93,000 kN for both the Kazakhstani and European approaches. The raft element of the piled raft foundation ensures additional bearing resistance at the ultimate limit state. The obtained value of bearing resistance allowed for calculating the values of elastic settlement for the piled raft foundation. The calculation of the elastic settlement of a piled raft foundation is performed by the application of the stiffness method for both the Kazakhstani and European approaches. The stiffness method considers the stiffness of the piled raft foundation in SP RK (i.e., $\mathrm{K}_{\mathrm{f}}$ ) and EC 7 (i.e., $\mathrm{K}_{\mathrm{PR}}$ ), as indicated in Equations (15) and (16), respectively. The Kazakhstani and European approaches provided $15 \mathrm{~cm}$ and $26 \mathrm{~cm}$ of elastic settlement, respectively, for the piled raft foundation. The pile group element of the piled raft foundation contributes to the reduction in the elastic settlement. Based on the obtained results, it can be concluded that EC 7 provides a more conservative design for piled raft foundations than SP RK.

In order to investigate the effect of different widths of raft foundations and different lengths of pile foundations, the results of sensitivity analysis are provided. Figures 7 and 8 show the bearing resistance for the Kazakhstani and European approaches with respect 
to different widths (2-20 m) of the raft foundation and different lengths $(3-15 \mathrm{~m})$ of the pile foundation, respectively. They show that DA1-2 and DA3 produce the same results of bearing resistance for raft and pile foundations due to the application of the same values of partial factors. In Figure 7, the results of raft foundation bearing resistance when adhering to DA1-1, DA1-2 and DA3, and DA2 of EC 7 with respect to SP RK values were 1.7 to 2.9, 1.0 to 1.5 , and 1.2 to 2.1 times higher, respectively, for different widths of the designed raft foundation. Also, in Figure 8, the bearing resistance with regard to pile foundation length revealed differences of 1.3 to $1.4,1.0$ to 1.1 , and 1.2 to 1.3 times for DA1-1 and DA3, DA1-2, and DA2, respectively, compared to SP RK values. The more conservative results of the European approach provide the possibility to design and construct buildings and structures with guaranteed serviceability and durability and high-quality construction. It was also demonstrated that Eurocode provides a higher level of safety and durability of buildings when compared to the Kazakhstani national regulations [7].

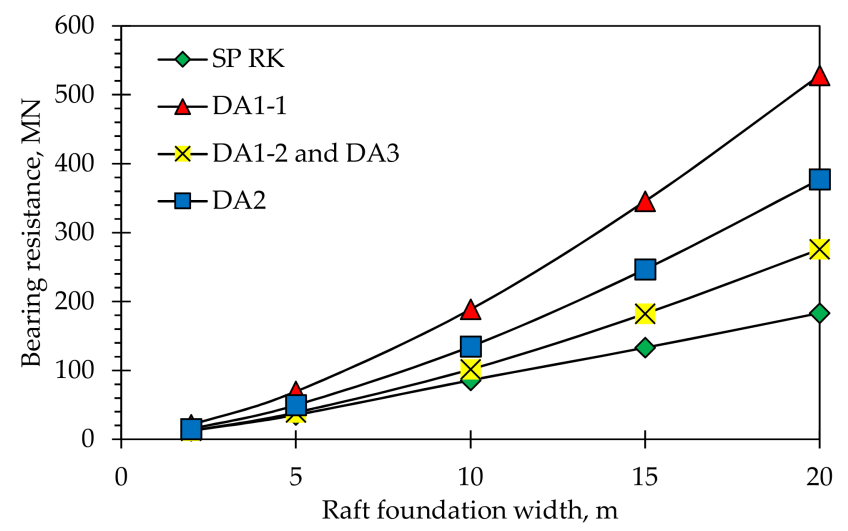

Figure 7. Bearing resistance of raft foundations of varying widths.

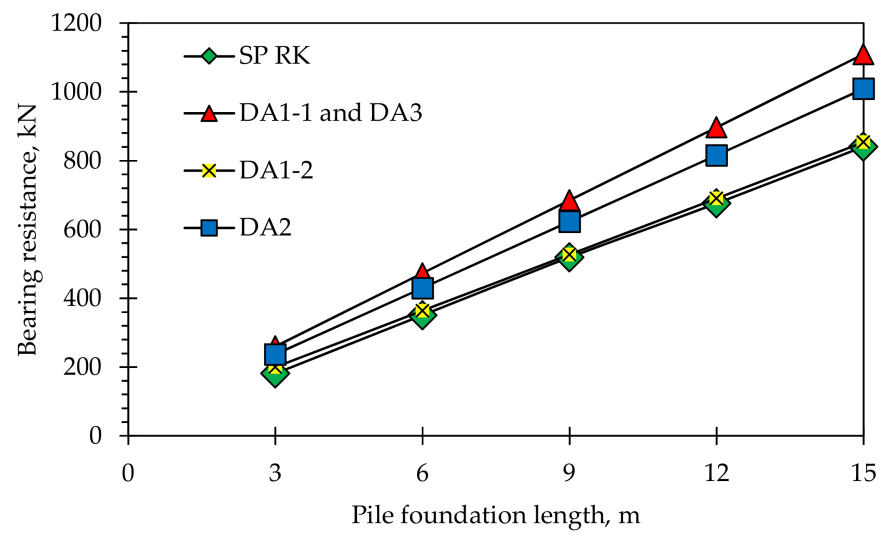

Figure 8. Bearing resistance of pile foundations of varying lengths.

\section{Summary and Conclusions}

In Kazakhstan, the transition from the current design code (SP RK) to Eurocode represents the easiest way to increase the rate and quality of construction works. The introduction of Eurocode in Kazakhstan allows for the elimination of technical barriers in international collaboration and the creation of a unified base for design and construction works. Moreover, the results of code harmonization can benefit scientific collaboration by establishing identical design methods, as well as common requirements for construction.

The harmonization of Kazakhstani building regulations with Eurocode requires the translation of the design code to the country's language, the performance of comparative analysis for the design of buildings and structures, and development of the National Annex (NA). The climatic, seismic, geological, and geographical features of Kazakhstan must be considered in the development of the NA. In addition, the transition process requires time 
to avoid misunderstanding of the applied design principles. In this study, the procedure for the design of raft, pile, and piled raft foundations adhering to Kazakhstani building regulations and Eurocode 7 is provided.

A comparative analysis of the considered design codes was performed based on the design example of Nur-Sultan city. Through this comparison, it was found that EC 7 provides general guidance, and further details are decided in accordance with NA, which would be more adaptable to different conditions as compared to SP RK. The design of raft, pile, and piled raft foundations showed that the obtained values of the bearing resistance, elastic settlement, and over-design factor adhering to the European approach exceeded the values from the Kazakhstani approach. The differences in these results were obtained due to the application of higher values of partial safety factors under EC 7. The ODF results adhering to the European approach were greater by $6 \%$ to $38 \%$ for both raft and pile foundations as compared to the results adhering to the Kazakhstani approach. It can be concluded that Eurocode 7 provides more conservative resultsand, thus, a higher safety level—than Kazakhstani building regulations. The performed sensitivity analysis of raft foundation width and pile foundation length for the bearing capacity also supported the conclusions regarding the conservativeness of the considered design codes. The conservativeness of the European approach is explained by the fact that EC 7 synthesizes the design traditions and construction practices of various European countries, so the integration process led to a more conservative and detailed geotechnical design approach than that in Kazakhstan. Further studies comparing the Kazakhstani and European approaches for geotechnical design are required to enhance the obtained results.

Supplementary Materials: The following are available online at https: / /www.mdpi.com/article / 10.3390/app11073099/s1, Figure S1: Relationship between the design resistance under the base of driven piles in clay soil $(R)$ and the liquidity index $(I L)$ (Table 1 of SP RK 5.01-103-2013-Pile foundations), Figure S2: Relationship between the design resistance on the shaft surface of driven piles (fi) and the liquidity index (IL) (Table 2 of SP RK 5.01-103-2013-Pile foundations), Figure S3: Relationship between the coefficients $\left(\mathrm{M}_{\gamma}, \mathrm{M}_{\mathrm{q}}, \mathrm{M}_{\mathrm{c}}\right)$ and friction angle $(\varphi)$ (Table 5 of SP RK 5.01-1022013-Foundations of buildings and structures).

Author Contributions: A.Z. and S.-W.M. conceptualized the study; A.Z., N.S. and S.-W.M. implemented data processing under the supervision of J.K. and A.S.; the original draft of the manuscript was written by A.Z., N.S. and S.-W.M. with editorial contributions from J.K., A.S. and D.L. All authors have read and agreed to the published version of the manuscript.

Funding: This research was funded by Nazarabyev University, Faculty Development Competitive Research Grant Program (FDCRGP) Grant No 110119FD4508.

Institutional Review Board Statement: Not applicable.

Informed Consent Statement: Not applicable.

Data Availability Statement: Not applicable.

Conflicts of Interest: The authors declare no conflict of interest.

\section{References}

1. Antonova, M.V.; Glushko, D.V.; Belyaeva, S.V.; Pakrastinsh, L. A comaparative analysis of European and Russian tecnhical documentaion of building materials. Строительство уникальных зданий и сооружений 2014, 4, 34-50. (In Russian)

2. Bazarbayev, N.K.; Ibraimova, S.S. Current state of the construction industry of the Republic of Каzakhstan. Экономика и управление вХXI веке: тенденции развития 2016, 33-1, 127-132. (In Russian)

3. Tolybekova, R.M.; Dyusebayev, D.M.; Besimbayev, E.T. Efficiency of the introduction of Eurocode based on the example of the foundation settlement calculation. Материаловедение 2016, 1, 40-43. (In Russian)

4. Volokh, K.S.; Artem, A.D.G.; Saprygina, Y.V.; Potekhin, A.A. Modern status of the normative base in construction. In Proceedings of the International Innovation Research, Penza, Russia, 7 August 2017; pp. 66-68. (In Russian).

5. Bisengaliyev, M.D.; Zaidemova, Z.K.; Mukhambetzhanova, K.K. Introduction of Eurocodes in the Republic of Kazakhstan. In Proceedings of the ПерспективыСоциально-экономического РазвитияСтран и Регионов, Astrakhan, Russia, 29-31 October 2019; pp. 131-134. (In Russian). 
6. Kurmaniyazova, N.Z. About the introduction of Eurocode in the Republic of Kazakhstan. In Proceedings of the Hаyка, Образование, Инновации: Апробация Результатов Исследований, Neftekamsk, Russia, 17 December 2019; pp. 134-140. (In Russian).

7. Saparbayev, E.Z.; Tulebekova, A.S. Features of reforming normative base of the Republic of Kazakhstan. Актуальные научные исследования в современном мире 2019, 6-1, 11-15. (In Russian)

8. Shaldykova, A.; Moon, S.-W.; Kim, J.; Lee, D.; Ku, T.; Zhussupbekov, A. Comparative Analysis of Kazakhstani and European Approaches for the Design of Shallow Foundations. Appl. Sci. 2020, 10, 2920. [CrossRef]

9. Orr, T. Implementig Eurocode 7 to achieve reliable geotechnical designs. In Modern Geotechnical Design Codes of Practice; IOS Press: Amsterdam, The Netherlands, 2013; pp. 72-86.

10. Lambla, V. Construction sector in Kazakhstan 2019. In Market Analysis and Development Forecasts for 2019-2024; PMR Market Insight: Krakow, Poland, 2019.

11. Almazov, V.O. Harmonization of the Russian building size standards. Вестник МГСУ 2011, 2-1, 84-88. (In Russian)

12. Kutuzov, V. Legal aspects of the harmonization of technical regulation of construction in Russia, the European Union, and Eurasian Economic Community. Хозяйство иПраво 2012, 11, 68-76. (In Russian)

13. Meena, N.K.; Nimbalkar, S. Effect of water drawdown and dynamic loads on piled raft: Two-dimensional finite element approach. Infrastructures 2019, 4, 75. [CrossRef]

14. Alibekova, N.T.; Zhussupbekov, A.Z. GIS Technology for Engineering and Geological Surveys; LAP LAMBERT Academic Publishing: Saarbrücken, Germany, 2018. (In Russian)

15. Cangir, B.; Dipova, N. Estimation of Undrained Shear Strength of Konyaalti Silty Clays. Indian J. Geo Mar. Sci. 2017, 46, 513-520.

16. Schofield, A.N.; Wroth, C.P. Critical State Soil Mechanics; McGraw-Hill: London, UK, 1968; p. 310.

17. Wroth, C.P.; Wood, D.M. The correlation of index properties with some basic engineering properties of soils. Can. Geotech. J. 1978, 15, 137-145. [CrossRef]

18. SP RK 5.01-103-2013—Pile Foundations; KAZGOR: Almaty, Kazakhstan, 2013.

19. Eurocode 7: Geotechnical Design-Part 1: General Rules. In British Standards; The European Union: Brussels, Belgium, 1997. (In Russian)

20. Bond, A.; Harris, A. Decoding Eurocode 7; CRC Press: Boca Raton, FL, USA, 2008.

21. Bond, A. Implementation and evolution of Eurocode 7. Mod. Geotech. Des. Codes Pract. Implement. Appl. Dev. $2012,1,3$.

22. Poulos, H.G.; Davis, E.H. Pile Foundation Analysis and Design. 1980. Available online: https://drive.google.com/file/d/ 0BxlQHeKi4f-6a0dBR3MzRmxUVDY0OW1tRzRMOTdoQQ/view (accessed on 3 October 2020).

23. SP RK 5.01-102-2013-Foundations of Buildings and Structures; KAZGOR: Almaty, Kazakhstan, 2013. (In Russian)

24. Katzenbach, R.; Bachmann, G.; Boled-Mekasha, G.; Ramm, H. Combined pile raft foundations (CPRF): An appropriate solution for the foundations of high-rise buildings. Sloak J. Civ. Eng. 2005, 3, 19-29.

25. Randolph, M.F. Design Methods for pile groups and pile rafts. In Proceedings of the XIII International Conference on Soil Mechanics and Foundation Engineering, New Delhi, India, 5-10 January 1994; pp. 61-82. 